\title{
NUCLEAR DNA AND THE EVOLUTION OF WHEAT
}

\author{
H. REES and M. R. WALTERS \\ Department of Agricultural Botany, University College of Wales, Aberystwyth
}

\section{INTRODUCTION}

Received 3.x.64

GIVEN that genotype is determined mainly by the genetic information vested in nuclear deoxyribose nucleic acid (DNA) we might expect differences between genotypes to be directly reflected by differences in nuclear DNA constitution. The differences could be of three kinds, (1) in the total amount of nuclear DNA, (2) in the DNA base ratios and (3) in the order of bases along the DNA chains. Where differences between genotypes are slight, as for example between individuals within the same population, it is of course unlikely that a DNA variation could be revealed by present methods of analysis. Differences in nuclear DNA have, however, been established in many instances between genotypes of widely dissimilar origin, e.g. from different species. There is evidence for a variation in the order of bases between nucleic acid, RNA in this case, of different strains of tobacco mosaic virus (Reddi, 1959). It is well known that the DNA base ratios vary between different species (Zamenhoff, 1952; Belozersky, 1961). Very large, tenfold, differences in nuclear DNA amount have been found between diploid species even from within the same genus, e.g. in Lilium (Sunderland and McLeish, 1961). These comparisons of nucleic acid composition have provided, among other things, particularly useful information about the kind of change in basic genetic material that underlies the divergence and diversity of genotypes during their evolution. In certain cases these comparisons can be used in the tracing of ancestry, particularly where hybridisation is involved. The following describes the use of such comparisons, based on nuclear DNA amount, for tracing the ancestry of the cultivated wheats.

\section{THE CULTIVATED WHEATS}

The more important cultivated wheats are allo-polyploids. The common bread wheat, Triticum estivum, is an allohexaploid with 42 chromosomes whereas others, such as the macaroni wheat Triticum durum, are allo-tetraploids with 28 chromosomes. Due mainly to the work of Kihara it is now generally agreed that one of the diploid ancestors, a Triticum of the $T$. monococcum type, contributed one of the genomes, $A$, found in both the tetraploid, $A A B B$, and in the hexaploid, $A A B B D D$. McFadden and Sears (1944a) and Kihara (1944) have traced the source of the $D$ genome found in the hexaploid to Egilops squarrosa. As for the $B$ genome, most authorities (e.g. Sarkar and Stebbins (1956) and Riley, Unrau and Chapman (1958)) believe that it derives from Egilops speltoides, whereas others favour Egilops bicornis (Sears, 1956) or an Agropyron such as A. triticeum. A brief summary of views on ancestry appears in table $\mathrm{I}$. 


\section{METHOD}

The method of using DNA comparisons as an approach to the problem of wheat ancestry is as follows. Estimates of nuclear DNA content are made of the diploid genomes. From combinations of these values predictions are made of the DNA values to be expected in the tetraploids and hexaploids. Comparisons between the predicted values and the actual estimates in polyploid species enable us to determine, in the first place, which of the diploid species postulated as having contributed the $B B$ genomes has a nuclear DNA content which, in combination with $A A$, agrees best with the value observed in $A A B B$, and hence which of the species is the more likely contributor of $B B$.

TABLE I

The chromosome constitutions proposed for the wheat and other related species investigated

\begin{tabular}{|c|c|c|c|}
\hline Species & & Constitution & \\
\hline $\begin{array}{l}T . \text { estivum } \\
T . \text { durum } \\
T . \text { dicoccum } \\
\mathcal{T} \text {. dicoccoides } \\
T . \text { timopheevi } \\
T \text {. monococcum } \\
T \text {. egilopoides }\end{array}$ & . & $\begin{array}{l}A A B B D D \\
A A B B \\
A A B B \\
A A B B \\
A A G G \\
A A \\
A A\end{array}$ & (Kihara, 1924; Lilienfield and Kihara, 1934) \\
\hline $\begin{array}{l}\text { E. speltoides } \\
\text { E. bicornis } \\
\text { A. triticeum } \\
\text { E. squarrosa }\end{array}$ & : & $\begin{array}{l}B B \\
B B \\
B B \\
D D\end{array}$ & $\begin{array}{l}\text { (Sarker and Stebbins, ז956; Riley, Unrau and } \\
\text { Chapman, } 195^{8} \text { ) } \\
\text { (Sears, I956) } \\
\text { (McFadden and Sears, I944a) } \\
\text { (McFadden and Sears, I944b; Kihara, ז944) }\end{array}$ \\
\hline
\end{tabular}

Secondly, comparisons between predicted and observed DNA combinations in polyploids and, also, comparisons between polyploid species of similar genome constitution give some indication of whether changes in nuclear DNA content have taken place subsequent to hybridisation and polyploidy. Finally, it is possible to test whether, as is claimed, certain of the polyploid wheats are of different genome constitution and hence of different origin, e.g. Triticum timopheevi $(A A G G)$ as compared with $T$. durum $(A A B B)$.

Technique. Measurements of DNA were made by spectrophotometry of $2 C$ nuclei at telophase or early interphase in root tips following Feulgen staining. The fixing and staining procedures used were those described by McLeish and Sunderland ( $196 \mathrm{I}$ ) and the measurements were made on a Barr and Stroud integrating microdensitometer.

In each series of measurements preparations were made on separate slides from root tips of one plant of each species in each of at least two replicates. The average DNA values were then estimated from ten ${ }_{2} C$ nuclei on each slide. The differences between replicates provide a measure of experimental error within each experiment.

\section{RESULTS}

\section{(i) Nuclear DNA in related species}

(a) AABB Tetraploids. It will be seen from table I that certain diploid and tetraploid species are reputed to be of similar chromosome constitution and, it follows, of similar ancestry. For example, three tetraploids are listed as $A A B B$ and two of the diploids, T. monococcum 
and $T$. egilopoides, are $A A$. It is worth while comparing the DNA values of the species within these groups. Given that the related species are indeed of common ancestry a similarity in their nuclear DNA content would indicate little or no change in DNA subsequent to divergence and speciation. Moreover, a similarity in the DNA content of the related species will, for the purpose of tracing the ancestry of cultivated forms, justify the use of DNA values from a particular species as representative of a particular genome or combination of genomes.

Mean DNA values for ${ }_{2} C$ nuclei of the three $A A B B$ tetraploids investigated are given in table 2. There is no significant DNA variation between the species. The similarity of their DNA content is completely consistent with their reputed common ancestry and, as well, indicative of a constancy in DNA amount subsequent to their divergence.

TABLE 2

$D N A$ values (in arbitrary units) from $2 \mathrm{C}$ root tip nuclei in $\mathrm{AABB}$ tetraploids. $D \mathcal{N A}$ values were estimated from 10 nuclei in each plant in each replicate

\begin{tabular}{|c|c|c|c|c|}
\hline & & T. durum & $T$. dicoccum & $\mathcal{T}$. dicoccoides \\
\hline $\begin{array}{l}\text { Replicate } 1 \\
\text { Replicate } 2\end{array}$ & • & $\begin{array}{l}26 \cdot 5 \\
26 \cdot 9\end{array}$ & $\begin{array}{l}26 \cdot 0 \\
27 \cdot 2\end{array}$ & $\begin{array}{l}27 \cdot 4 \\
26 \cdot 7\end{array}$ \\
\hline Mean DNA & & $26 \cdot 7$ & $26 \cdot 6$ & $27 \cdot 1$ \\
\hline
\end{tabular}

Although the chief aim of these present comparisons was to ascertain what variation, if any, could be found between the DNA of species of the same genome constitution in seemed worthwhile extending the comparisons of tetraploids to include $T$. timopheevi which is reputed by some authorities to have a chromosome constitution unlike that of the T. durum type.

(b) AABB and AAGG tetraploids. T. timopheevi, it is claimed, has a different chromosome constitution $(A A G G)$ from that of the $A A B B$ 's described above. The first comparison between an $A A B B$, namely $T$. durum, and the $A A G G T$. timopheevi indicated that a difference in origin was reflected also in a difference in nuclear DNA. A further four series of measurements were consequently made to see whether the difference could be confirmed. The complete data appear in table 3 and an analysis of variance of these data in table 4 . It will be observed that the DNA difference, though small, is significant. The conclusion is that the nuclei of $A A G G, T$. timopheevi, have a lower DNA content than those of the $A A B B T$. durum. This DNA difference in itself docs not of course establish a completely separate ancestry for T. timophecvi. It could be that DNA changes occurred subsequent to a common origin with that of $T$. durum and other $A A B B$ tetraploids (see Sachs, I953; Wagenaar, I96I). If on the other hand the DNA difference does indeed reflect the separate ancestry inferred for 
T. timopheevi from other kinds of evidence, then the, unknown, $G$ genome must have a lower DNA content than the $B$, in order to account for the lower DNA value for $A A G G$ as compared with $A A B B$.

TABLE 3

Mean DNA in ${ }_{2} \mathrm{C}$ nuclei of $\mathrm{T}$. durum and $\mathrm{T}$. timopheevi." Estimates from five separate series

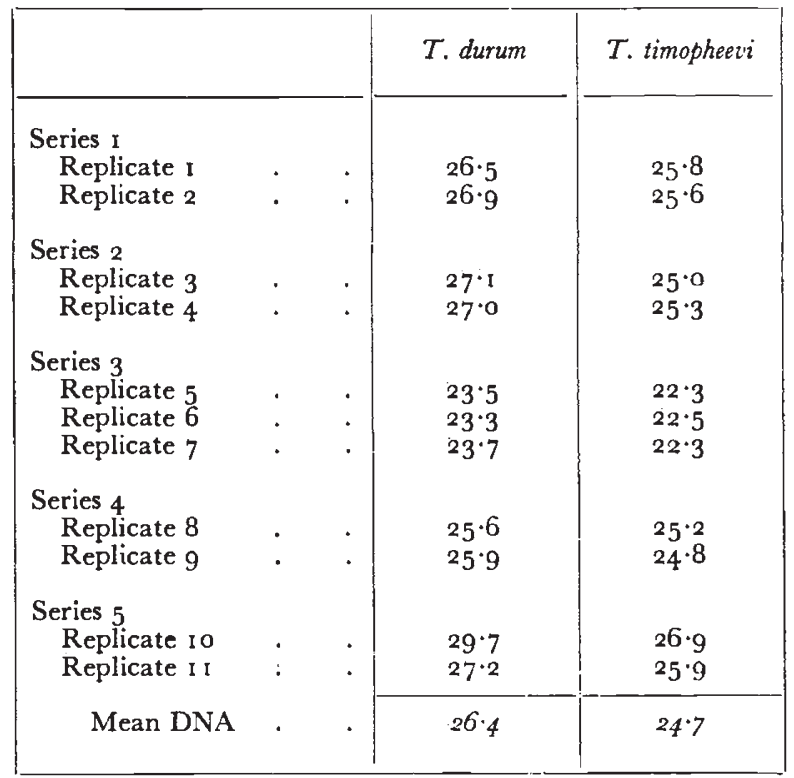

(c) $A A$ diploids. The data in table 5 are from two of the $A A$ diploids, $T$. monococcum and $T$. agilopoides. As will be observed there is no significant difference between their nuclear DNA contents.

TABLE 4

An analysis of variance of $D \mathcal{N} A$ variation between $\mathrm{T}$. durum and $\mathrm{T}$. timopheevi

\begin{tabular}{|c|c|c|c|c|c|c|}
\hline Item & & $S S$ & $\mathcal{N}$ & $M S$ & $V R$ & $P$ \\
\hline $\begin{array}{l}\text { Between species } \\
\text { Between series } \\
\text { Within series } \\
\text { Error }\end{array}$ & $\begin{array}{l}. \\
:\end{array}$ & $\begin{array}{r}9 \cdot 96 \\
57 \cdot 40 \\
3 \cdot 10 \\
2 \cdot 25\end{array}$ & $\begin{array}{r}1 \\
4 \\
6 \\
10\end{array}$ & $\begin{array}{r}9 \cdot 96 \\
14 \cdot 35 \\
0 \cdot 52 \\
0 \cdot 23\end{array}$ & $\begin{array}{c}43 \cdot 30 \\
62 \cdot 39 \\
2 \cdot 26 \\
\ldots\end{array}$ & $\begin{array}{c}<0 \cdot 01 \\
<0 \cdot 01 \\
0 \cdot 1-0 \cdot 2 \\
\quad \ldots\end{array}$ \\
\hline Total & . & $72 \cdot 71$ & 21 & $\ldots$ & $\ldots$ & $\ldots$ \\
\hline
\end{tabular}

From comparisons of both diploids and tetraploids it appears that the nuclear DNA amount is the same within species whose genome constitution is known to be similar. This result is hardly surprising and is completely consistent with a common ancestry. In tracing the 
ancestry of the cultivated wheats it means also that we can use measurements from a single species of a particular genome constitution with reasonable confidence that the species will be representative of the particular genome type.

TABLE 5

DNA estimates in $\mathrm{T}$. monococcum and $\mathrm{T}$. ægilopoides

\begin{tabular}{|c|c|c|c|c|}
\hline & & & T. monococcum & T. egilopoides \\
\hline Series I & & & & \\
\hline Replicate I & . & . & II $\cdot I$ & I I $\cdot 8$ \\
\hline Replicate 2 & . & . & I I 'O & $12 \cdot 0$ \\
\hline Series 2 & & & & \\
\hline Replicate 3 & . & . & 14.9 & 14.8 \\
\hline Replicate 4 & . & . & 15.0 & $14 \cdot 8$ \\
\hline Mean DNA & . & . & $13 \cdot 0$ & $13 \cdot 4$ \\
\hline
\end{tabular}

\section{THE TRACING OF ANCESTRY}

Data for nuclear DNA in the diploid and polyploid species are given in table 6. For convenience in comparing the results of the different series of estimates these data have been weighted such that the

TABLE 6

$D \mathcal{N A}$ values in diploids and polyploids. The values are weighted so that means of replicates correspond (see text)

\begin{tabular}{|c|c|c|c|c|c|c|c|}
\hline & $\begin{array}{c}T . \\
\text { monococcum }\end{array}$ & $\begin{array}{c}E \\
\text { speltoides }\end{array}$ & E. bicornis & $\begin{array}{c}\text { A. } \\
\text { triticeum }\end{array}$ & $\begin{array}{c}\mathscr{E} . \\
\text { squarrosa }\end{array}$ & T. durum & $\underset{\text { estivum }}{T .}$ \\
\hline Series I & & & & & & & \\
\hline $\begin{array}{l}\text { Replicate I } \\
\text { Replicate } 2\end{array}$ & $20 \cdot 2$ & $16 \cdot 8$ & $2 \mathrm{I} \cdot 8$ & $\cdots$ & $16 \cdot 3$ & $36 \cdot 2$ & $53 \cdot 9$ \\
\hline Series 2 & & & & & & & \\
\hline Replicate 3 & $19 \cdot 5$ & $17 \cdot 6$ & $2 \mathrm{I} \cdot 8$ & $15 \cdot 4$ & 15.6 & $37 \cdot 7$ & $53 \cdot 2$ \\
\hline Replicate 4 & $2 \mathrm{I} \cdot 2$ & 17.9 & 23.5 & 13.8 & 14.7 & 37.0 & $52 \cdot 6$ \\
\hline Series 3 & & & & & & & \\
\hline Replicate 5 & 19.5 & $18 \cdot 0$ & $20 \cdot 9$ & $\ldots$ & $\ldots$ & $3^{8 \cdot I}$ & $\ldots$ \\
\hline Keplicate b & $21 \cdot 0$ & $18 \cdot 7$ & $20 \cdot 9$ & $\cdots$ & $\cdots$ & $3^{6 \cdot 9}$ & $\cdots$ \\
\hline Mean DNA & $2 a \cdot 5$ & $17 \cdot 8$ & $2 I \cdot 8$ & $14 \cdot 6$ & 15.6 & $37 \cdot 0$ & $53 \cdot 0$ \\
\hline
\end{tabular}

mean overall DNA values are the same for each replicate. This weighting does not of course invalidate the significance of DNA comparisons between species.

From the table and from fig. I, in which the results of a typical series are plotted in the form of histograms, it will be observed, first, that there is a considerable and consistent DNA variation between 
certain of the diploid species. Agropyron triticeum and Agilops squarrosa have especially low nuclear DNA values whereas the nuclear DNA content is relatively much greater in $T$. monococcum and $A$. bicornis. Divergence and speciation in these instances are clearly accompanied

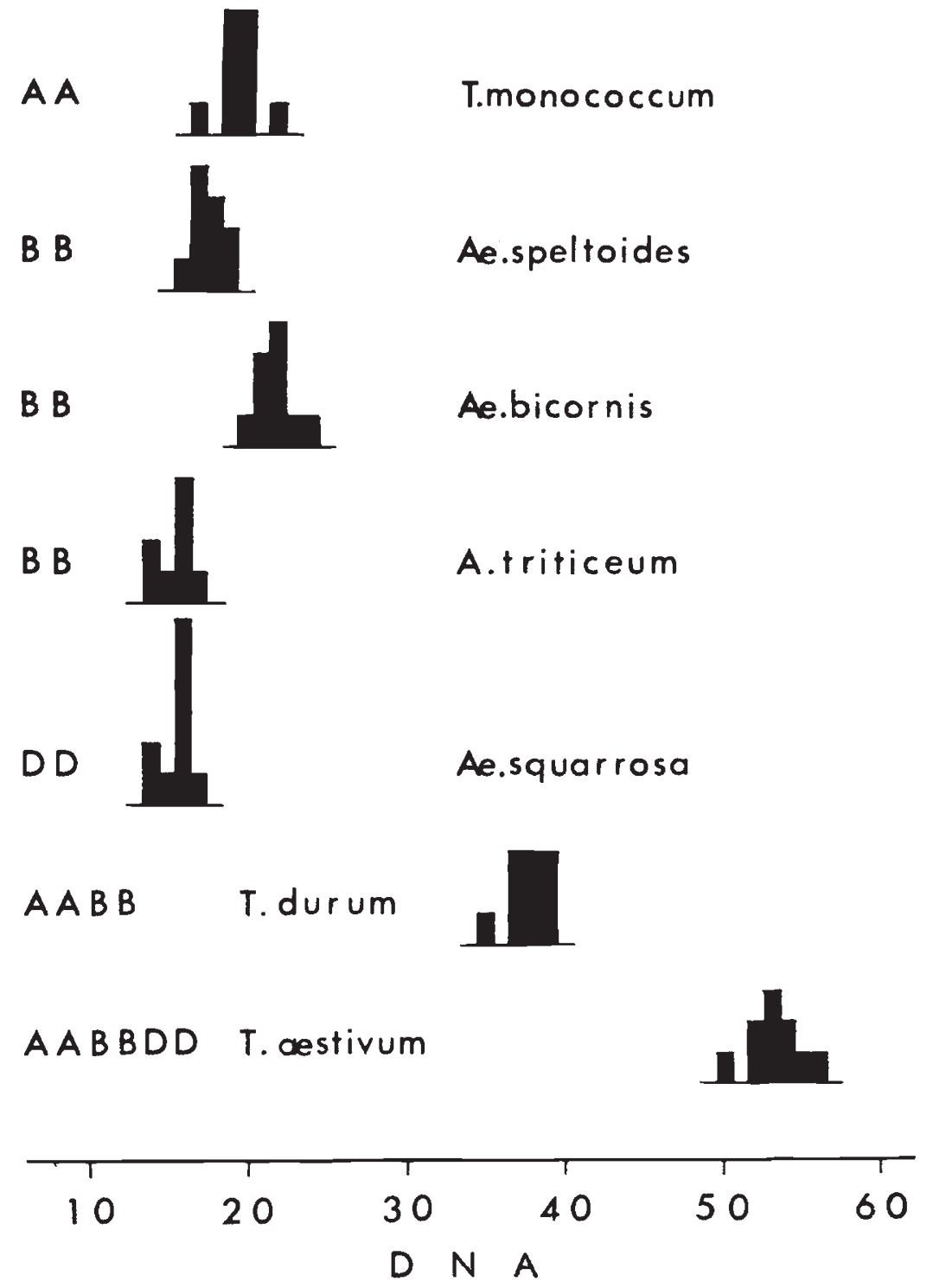

FIG. 1.-Histograms of the distributions of DNA amounts estimated in ${ }_{2} C$ nuclei of diploids and polyploids among cultivated and related species of wheat.

by, and to some degree are perhaps a consequence of, change in chromosomal DNA amount. Second, it will be seen that the tetraploid and hexaploid DNA values are approximately twice and three times larger, respectively, than those of the diploids. There is no evidence, 
either for an appreciable diminution, or for an increase of DNA per chromosome associated with the polyploidy. Further reference to this aspect of the evolution of the polyploids will be made in a later section.

The ancestry of AABB. As has been mentioned earlier there is general agreement that the $A A$ chromosomes found in both the $A A B B$ tetraploids and the $A A B B D D$ hexaploids are derived from a Triticium of the monococcum type. The three main contenders as a source of the $B B$ chromosomes are $A E$. speltoides, $\not E$. bicornis and $A$. triticeum. On the assumption that $A A$ does indeed originate from a $T$. monococcum type and that the $T$. monococcum investigated is typical of the $A A$ species, as

TABLE 7

Predicted and observed DNA values for AABB. (Data from table 6)

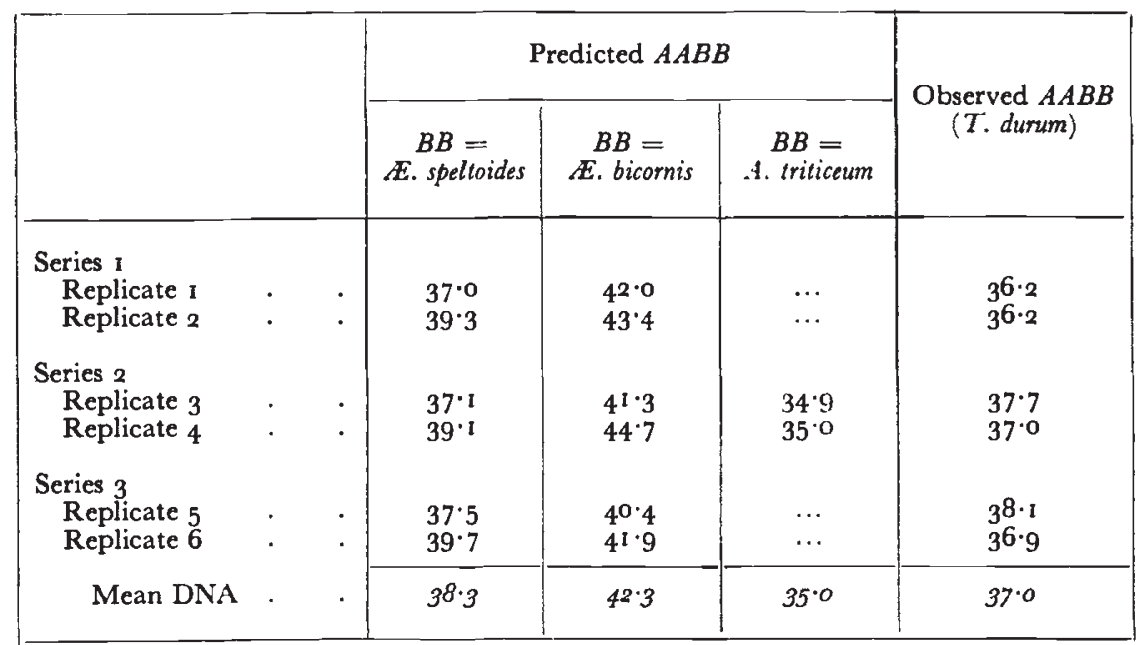

appeared justified from the comparisons described earlier, it is an easy matter to list the DNA values expected in $A A B B$ where $E$. speltoides, $A$. bicornis and $A$. triticeum are the respective contributors of $B B$. These predicted values from each series of estimates appear in table 7. Also in the table are the values observed in the $A A B B T$. durum. From these data it is apparent that predictions based on $E$. speltoides are by far the closest to the values observed for $A A B B$. An analysis of variance of the variation between predicted and observed $A A B B$ values confirms that there is no significant difference between them when $B B$ is assumed to derive from $E$. speltoides ( $\mathrm{P}=>0 \cdot 10)$. In contrast predictions based on $A$. bicornis and $A$. triticeum are significantly too high (P $=0.0 \mathrm{I}-0.00 \mathrm{I})$ and too low $(\mathrm{P}=<0.05)$ respectively. On the strength of this cvidence $A$. speltoides is the most likely of these three species to be the source of the $B B$ genome.

AABB and AABBDD. The evidence of McFadden and Sears (1944a) and of Kihara (1944) for E. squarrosa being the contributor of the $D D$ chromosomes is very strong indeed and the expectation therefore is that the sum of DNA values for $\mathcal{T}$. durum $(A A B B)$ and 
$E$. squarrosa $(D D)$ should equal that for $T$. estivum $(A A B B D D)$. Table 8 shows that $A A B B+D D$ is indeed very close to the observed $A A B B D D$. An analysis of variance confirms there is no significant difference between them.

TABLE 8

Predicted and observed DNA values for AABBDD. (Data from table 6)

\begin{tabular}{|c|c|c|}
\hline & Predicted $A A B B D D$ & Observed $A A B B D D$ \\
\hline $\begin{array}{l}\text { Series I } \\
\quad \text { Replicate I . } \\
\text { Replicate } 2\end{array}$ & $\begin{array}{l}52 \cdot 5 \\
52 \cdot 1\end{array}$ & $\begin{array}{l}53 \cdot 9 \\
52 \cdot 1\end{array}$ \\
\hline $\begin{array}{l}\text { Series } 2 \\
\quad \text { Replicate } 3 \\
\text { Replicate } 4 .\end{array}$ & $\begin{array}{l}53 \cdot 3 \\
51 \cdot 7\end{array}$ & $\begin{array}{l}53 \cdot 2 \\
52 \cdot 6\end{array}$ \\
\hline Mean DNA & $52 \cdot 4$ & $53 \cdot 0$ \\
\hline
\end{tabular}

\section{DISCUSSION}

The analysis of nuclear DNA variation provides a useful approach to investigating ancestry. In the wheats it provides new evidence on the diploid source of genomes comprising the cultivated polyploid forms. It shows also that, in this group at least, the hybridisation and subsequent polyploidy are accomplished without appreciable alteration in the DNA content of individual chromosomes. A previous report by Pai, Upadhya, Bhaskaran and Swaminathan (I96I) of a chromosome diminution of the order of about 30 per cent. in the wheat polyploids is shown to be incorrect as indeed is also made clear in a subsequent report by two of the above authors (Upadhya and Swaminathan, 1963). There is thus no evidence in wheat for a DNA diminution or for the associated change in the structural organisation of chromosomes inferred in polyploid Hemiptera (Schrader and HughesSchrader, 1956, 1958).

There are, of course, impediments to beware of in applying this kind of DNA analysis to problems of ancestry. The first relates to the accuracy of the DNA determinations and hence to the precision of the analysis. In this respect a most obvious precaution is to make all preparations in as near standard conditions as possible. This means that wherever possible the material from all species or types selected for comparison should be fixed, stained and scored together in the same batch. This is particularly important in eliminating variation in Feulgen staining, one of the chief sources of error variation.

Another objection that could be made to the method and to the validity of the conclusions derived from it is that the samples or varietics of the species used may not be typical (see Upadhya and Swaminathan, loc. cit.). Short of making widespread surveys within cultivated and other species there is no certain way of telling to what extent thc 
objection is valid. At the same time it was shown that, where tested, no significant differences in DNA amount occurred between different species known to have the same genome constitution. It is therefore a reasonable assumption that DNA differences between varieties within species are not likely to be greater and, hence, likely to be negligible.

\section{CONCLUSIONS AND SUMMARY}

I. Comparisons are described of $2 C$ nuclear DNA amounts, measured by Feulgen photometry, in cultivated and related species of wheat.

2. DNA amounts were the same in species of similar genome constitution investigated, viz. $A A$ or $A A B B$.

3. Triticum timopheevi, usually classified $A A G G$, has a lower nuclear DNA amount than $T$. durum $(A A B B)$.

4. Egilops speltoides, on the basis of DNA comparisons, is a more likely contributor of the $B$ genome found in the cultivated $A A B B$ tetraploids and $A A B B D D$ hexaploid than $E$. bicornis or Agropyron triticeum.

5. There is no evidence of appreciable change in nuclear DNA subsequent to the hybridisation and polyploidy by which the cultivated wheats arose.

Acknowledgments.-We are indebted to Mr W. I. C. Davies who made some of the DNA measurements and to Dr G. D. H. Bell and Dr R. Riley of the Plant Breeding Institute, Cambridge, who kindly supplied the wheat and other material used in this work.

\section{REFERENCES}

BELOZERSKY, A. N. 1961. The specificity of nucleic acid according to species. Proc. Vth International Congress of Biochemistry. Symposium No. III.

кihara, H. 1944. Die Entdeckung des DD-Analysators beim Weizen. Agric. Hort. Japan., 19, 889-89o.

lilienfield, F. A., AND Kimara, H. 1934. Genomanalyse bei Triticum und Agilops. V. Triticum timopheevi Zhuk. Cytologia, 6, 87-122.

MCFADDEN, E. S., AND SEARS, E. R. I944a. The artificial synthesis of Triticum spelta. Rec. Genet. Soc. Am., I3, 26-27.

MCFADDEN, E. S., AND SEARS, E. R. 1944b. The origin of Triticum spelta and its freethreshing hexaploid relatives. Four. Her., 37, 8I-89.

MCLEISH, J., AND SUNDERLAND, N. I961. Measurements of deoxyribose nucleic acid (DNA) in higher plants by Feulgen photometry and chemical methods. Exp. Cell Res., 24, 527-540.

PAI, R. A., UPADHYA, M. D., BHASKaVAN, s., AND swaminathan, M. s. I96i. Chromosome diminution and evolution of polyploid species in Triticum. Chromosoma, I 2, 398-409.

REDDI, K. K. 1959. The arrangement of purine and pyrimidine nucleotides in Tobacco Mosaic Virus nucleic acid. Proc. Nat. Aca. Sci., 45, 3, 293-300.

RILEY, R., UNRAU, J., AND CHAPMAN, v. 1958. Evidence on the origin of the $B$. genome of wheat. Jour. Her., 44, $91-98$.

sachs, L. 1953. Chromosome behaviour in species hybrids with Triticum timopheer $i$. Heredity, 7, 49-58.

SARKAR, P., AND STEBbins, G. L. 1956. Morphological evidence concerning the origin of the $B$ genome in wheat. Amer. Jour. Bot., 43, 297-304. 
SCHRAder, F., AND hUGHes-SChrader, S. 1956. Polyploidy and fragmentation in the chromosomal evolution of various species of Thyanta (Hemiptera). Chromosoma, $7,469-480$.

SCHRADER, F., AND HUGHeS-Schrader, s. 1958. Chromatid autonomy in Banasa (Hemiptera: Pentatomidal). Chromosoma, 9, 193-200.

SEARS, E. R. I956. The $B$ genome in wheat. Wheat Inf. Service, 4, 8-1o.

SUNDERLAND, N., AND MCLEISH, J. I96I. Nucleic acid content and concentration in root cells of higher plants. Exp. Cell Res., 24, 541-554.

UPADHYA, M. D., AND SWAminathan, M. S. 1963. Deoxyribonucleic acid and the ancestry of wheat. Nature, 200, 7I 3-7I4.

WagenaAR, E. B. I96 I. Studies on the genome constitution of Triticum timopheevi Zhuk. I. Evidence for genetic control of meiotic irregularities in tetraploid hybrids. Canadian Fourn. Gen. and Cytol., 3, 47-6o.

ZAMENHOFF, s. 1952. Newer aspects of the chemistry of nucleic acids. In Phosphorus Metabolism II, Johns Hopkins Univ. Press, Baltimore, 30 I-328. 